\title{
Diabetes mellitus: A journey of insulin
}

\author{
*Dewan Taslima Akhter, Rajia Sultana Nijhu \\ Department of Pharmacy, Stamford University Bangladesh, Dhaka-1217, Bangladesh
}

\begin{abstract}
Diabetes mellitus is a chronic ailment that impairs the production of or response to insulin, a hormone that helps to convert food into energy. Its complications are responsible for excess morbidity and mortality, loss of independence and reduce quality of life. Among the major cause of disablement and early death are ischemic heart disease, retinopathy, nephropathy, peripheral vascular disease and neuropathy. Insulin replacement therapy has been used in the clinical management of diabetes mellitus for more than 85 years. As subcutaneous injection is a painful episode so various approaches like transdermal, pulmonary, intranasal, colon targeted delivery, oral delivery is tried as an alternative way. Among them oral delivery is the challenging one because insulin cannot administered orally due to rapid enzymatic digestion in stomach. For oral delivery various technology, formulation and various modification approaches are going on. It is high time to invent an acceptable non-invasive insulin delivery for the diabetes to improve patient compliance and decrease the morbidity.
\end{abstract}

Key Words: Insulin, Approaches, Obstacles, Route of administration, Non-invasive.

\section{INTRODUCTION}

Diabetes mellitus is a common disease and its complications are responsible for excess morbidity and mortality, loss of independence, and reduced quality of life (Giriraj et al., 2003; Ahmed et al., 2006). Diabetes mellitus is a serious pathologic condition that is responsible for major healthcare problems worldwide and costing billions of dollars annually. The prevalence of diabetes continues to increase steadily as more people live longer and grow heavier. Type-1 diabetes comprises those forms of diabetes that are primarily due to insulin deficiency. Type-2 diabetes comprises those forms that result from a primary defect in insulin resistance (often associated with obesity), coupled with a relative insulin deficiency. Eventually, progressive loss of insulin producing $\beta$-cell of pancreas function in type-2 diabetes creates an absolute insulin deficiency and complicated by glucose (glucosamine) and lipid mediated toxicities.

\section{The American Diabetes Association recently}

\footnotetext{
*Corresponding Author:

Dewan Taslima Akhter, Lecturer

Department of Pharmacy, Stamford University Bangladesh

51, Siddeswari Road, Dhaka- 1217, Bangladesh

E-mail: shimulju@yahoo.com

Contact No.: +8801728384614
}

recommended an etiological classification of diabetes (2003). Type I diabetes normally occurs in childhood, has relatively acute onset, and requires insulin for survival. Insulin is a hormone made by the pancreas. With each meal insulin is released to help the body use or store the glucose (sugar) it gets from food. People with type I diabetes make no insulin. People with type II diabetes make some insulin, but not enough. For many people with type 2 diabetes the insulin has a harder time working.

\section{THE HISTORY OF INSULIN}

Nearly 100 years have passed since Von Mering and Minkowski first demonstrated that pancreatectomized dogs exhibited signs and symptoms characteristic of diabetes mellitus (Banting et al., 1922; Dhawan et al., 2009). The brief history of different approaches regarding insulin is tabulated in table 1.

\section{ROUTE OF ADMINISTRATION OF INSULIN}

Subcutaneous route is the present mode of administration of insulin. Other non-invasive mode of administration is under investigation though 
Table 1: Different events about insulin over the last decades.

\begin{tabular}{|c|c|c|}
\hline Year & Events & Reference \\
\hline 1921 & $\begin{array}{l}\text { Fredrick G. Banting, Charles H. Best, J.J.R. Macleod and James B. } \\
\text { Collip discovered insulin, a peptide which lowers blood sugar. }\end{array}$ & Bliss et al., 1982 \\
\hline 1922 & Bovine insulin was first administered to human. & Bliss et al., 1982 \\
\hline 1936 & Development of protamine, slow release insulin. & Jersild et al., 1956 \\
\hline 1944 & Standard syringe was released. & Maheux \\
\hline 1950 & Isophane NPH (neutral protamine Hagedorn) insulin. & Jersild et al., 1956 \\
\hline 1951 & $\begin{array}{l}\text { Amorphous 'lente' insulins (IZS) - semilente, lente and ultra-lente - } \\
\text { were developed. }\end{array}$ & Jersild et al., 1956 \\
\hline 1956 & First antidiabetic oral drug - sulfonamide was invented. & $\begin{array}{l}\text { Spencer et al., 1956; Ho et al., 1991; } \\
\text { Balsells et al., } 1997\end{array}$ \\
\hline 1963-1966 & Human insulin was chemically synthesized. & $\begin{array}{l}\text { Meienhofer et al., 1963; Kung et al., } \\
\text { 1966; Katsoyannis et al., } 1966\end{array}$ \\
\hline 1970 & Insulin pump was first used. & Maheux \\
\hline 1974 & $\begin{array}{l}\text { Highly purified animal insulin (less than } 1 \mathrm{pmol} / \mathrm{L} \text { of protein } \\
\text { impurities) was introduced. }\end{array}$ & Teuscher et al., 1974 \\
\hline 1975 & Fully synthetic insulin (CGP 12 831) was synthesized. & Teuscher et al., 1979 \\
\hline 1978 & Insulin production started from E. Coli. & Keen et al., 1980 \\
\hline 1980 & First recombinant DNA 'human' insulin. & Keen et al., 1980 \\
\hline 1982 & FDA approved Humulin R (rapid) and Humulin N (NPH). & Maheux \\
\hline 1986 & Insulin pen was first introduced. & Maheux \\
\hline 2006 & Pfizer invented inhaled insulin - Exubera ${ }^{\circledR}$. & Imam, 2011 \\
\hline
\end{tabular}

pulmonary delivery show similar efficacy to injected insulin.

\section{Subcutaneous route}

The present mode of insulin administration is by the subcutaneous route by which insulin is presented to the body in a non-physiological manner. Insulin injected subcutaneously at least twice a day is having many inherent disadvantages include local pain, inconvenience of multiple injections, and occasional hypoglycemia as a result of overdose, itching, allergy, hyperinsulinemia, and insulin lipodystrophy around the injection site. Lastly,

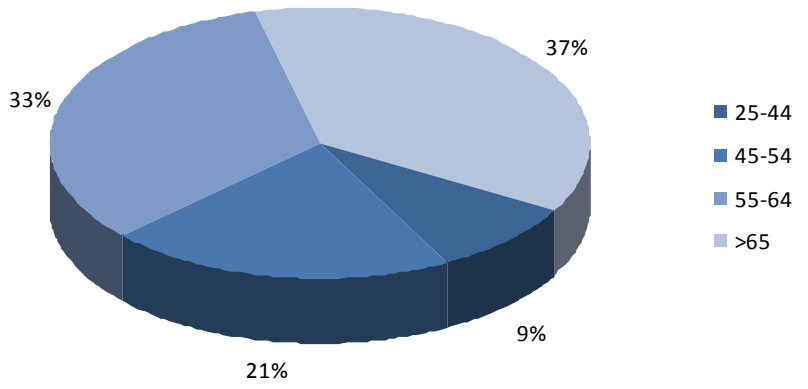

Figure 1: Distribution of diabetic patients according to age group. clinical trials have shown that even on injectable insulin treatment, a significant percentage of patients fail to attain lasting glycemic control due to non-compliance (Pamnani et al., 2008).

\section{Approaches for Non-invasive Insulin Delivery}

Despite the newer insulin formulations and strategies that allow the clinician to mimic normal endogenous insulin secretory profiles, intensive insulin therapy has not achieved widespread acceptance because of barriers to its use from both patients and physicians. Specifically, there may be concerns from the patient about fear, inconvenience, pain or the anxiety of insulin injections (Graff et al., 1998; Maisey et al., 1999). Furthermore, the patient may feel as if they are advancing to insulin therapy because they have been noncompliant with their treatment regimen (Hunt et al., 1997).

\section{Transdermal approach}

There are several methods for transdermal delivery of insulin. Pulsatile insulin uses microjets to pulse insulin into the patient, mimicking the physiological secretions of insulin by the pancreas (Arora et al., 2007). 


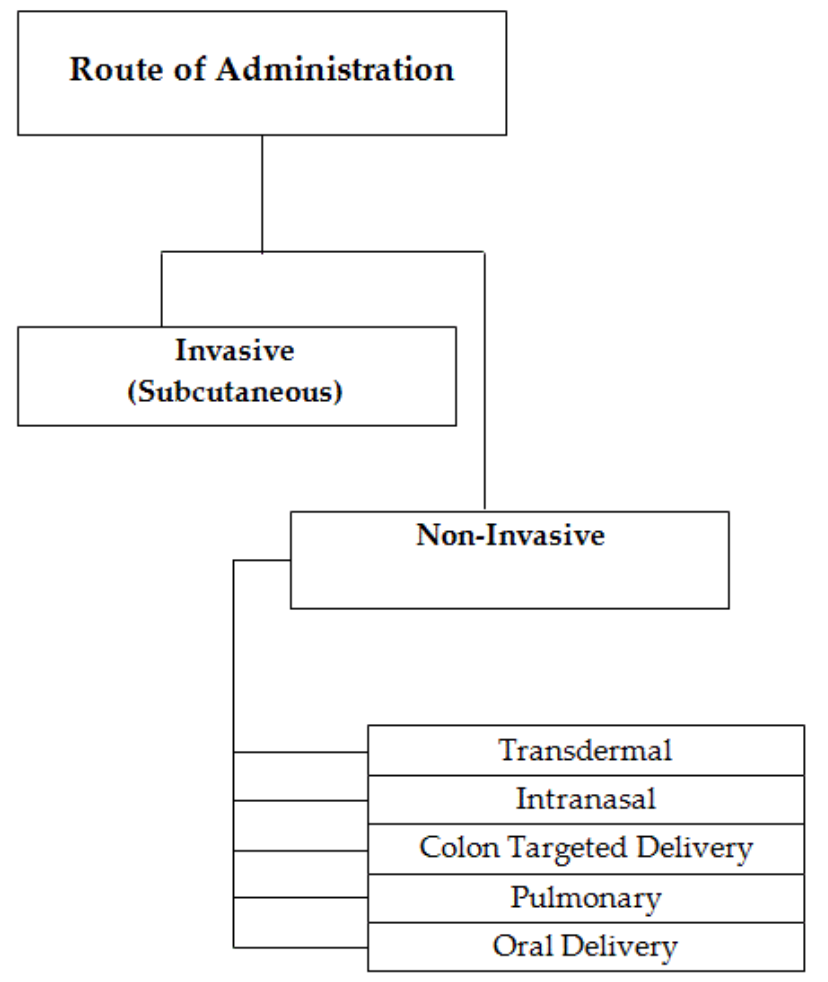

Figure 2: Route of administration of Insulin (Cefalu et al., 2004; Dhawan et al., 2009; Kinesh et al., 2010).

\section{Intranasal Approach}

Delivery of insulin using an intranasal approach was first suggested over 65 years ago, but it was not until the 1980s that this approach was seriously evaluated (Major et al., 1995; Saudek et al., 1997). Feasibility has been demonstrated, as intranasal insulin (60 or 120U) given pre-meal to 17 patients with type 2 diabetes and compared with placebo resulted in reductions in postprandial glucose at both 60 and 120 minutes (Coates et al., 1995). However, the major limitation of this approach is poor bioavailability across the mucous membranes. This was demonstrated in studies by Hilsted et al. (1995) as they reported doses of intranasal insulin that were approximately 20 times higher than those needed with subcutaneous injection To overcome the problem of limited bioavailability, absorptionenhancing compounds such as bile salts and polyethylene ether derivatives have been evaluated for nasal insulin and have resulted in increased absorption and effective biological activity. It appears, however, that the chance of nasal irritation has increased with these changes (Gizurarson et al., 1991; Jacobs et al., 1993). The feasibility of intranasal insulin has been demonstrated, but limitations do

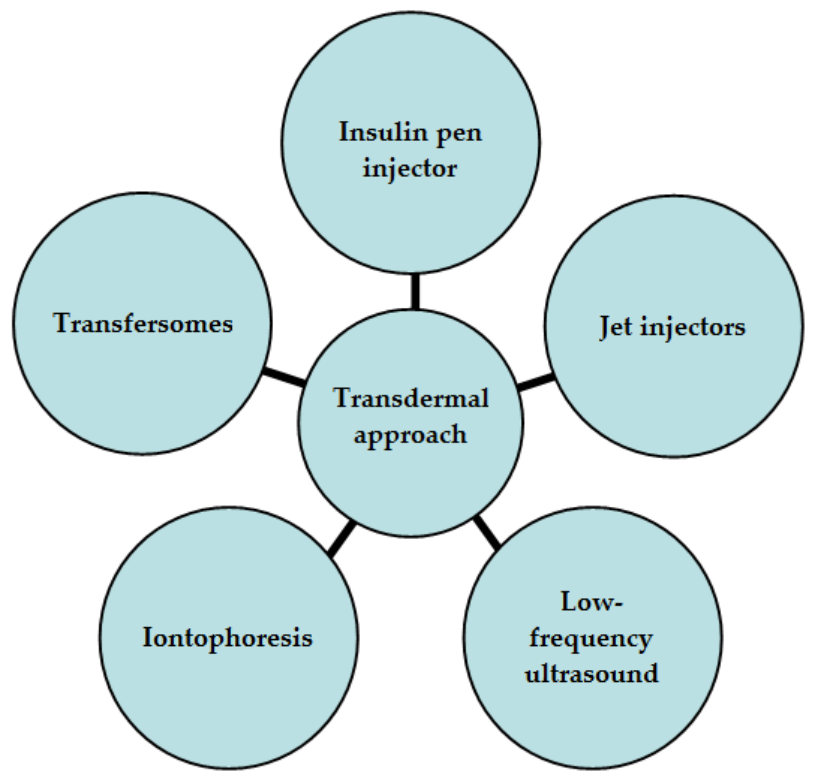

Figure 4: Different types of transdermal approaches (Golden et al., 1988, Mitragotri et al., 1995; Saudek et al., 1997; Stieber et al., 1998; Kanikkannan et al., 1999; Bohannon et al., 1999;; Rosenstock et al., 2001; Dixit et al., 2007).

exist and further studies are needed to establish long-term safety and efficacy.

\section{Colon-targeted delivery systems}

Proteolytic enzymes in the stomach degrade insulin, but in intestines peptidase activity is low and drainage into lymph is maximized. Researchers are exploring colon-specific delivery for insulin. To achieve colon specific delivery of insulin, Hideyuki prepared azopolymer-coated pellets containing

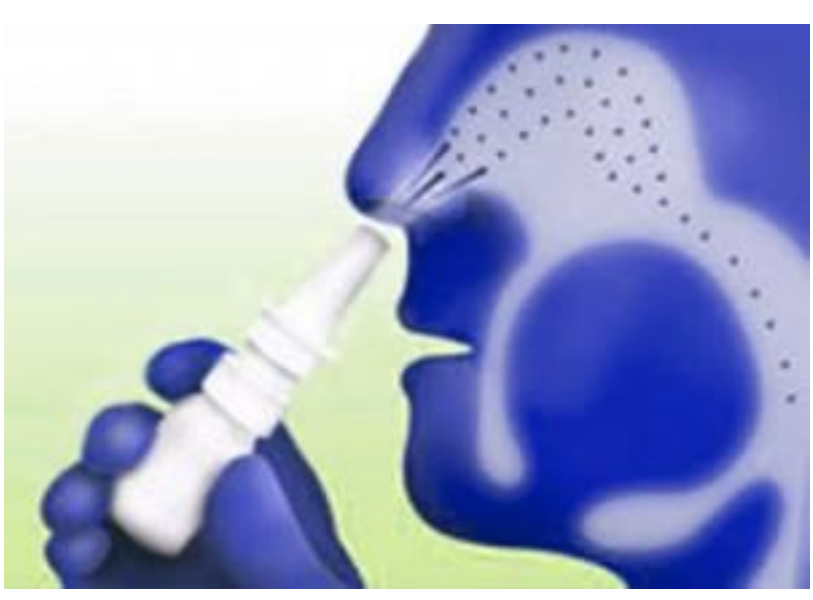

Figure 5: Intranasal route for insulin delivery. 


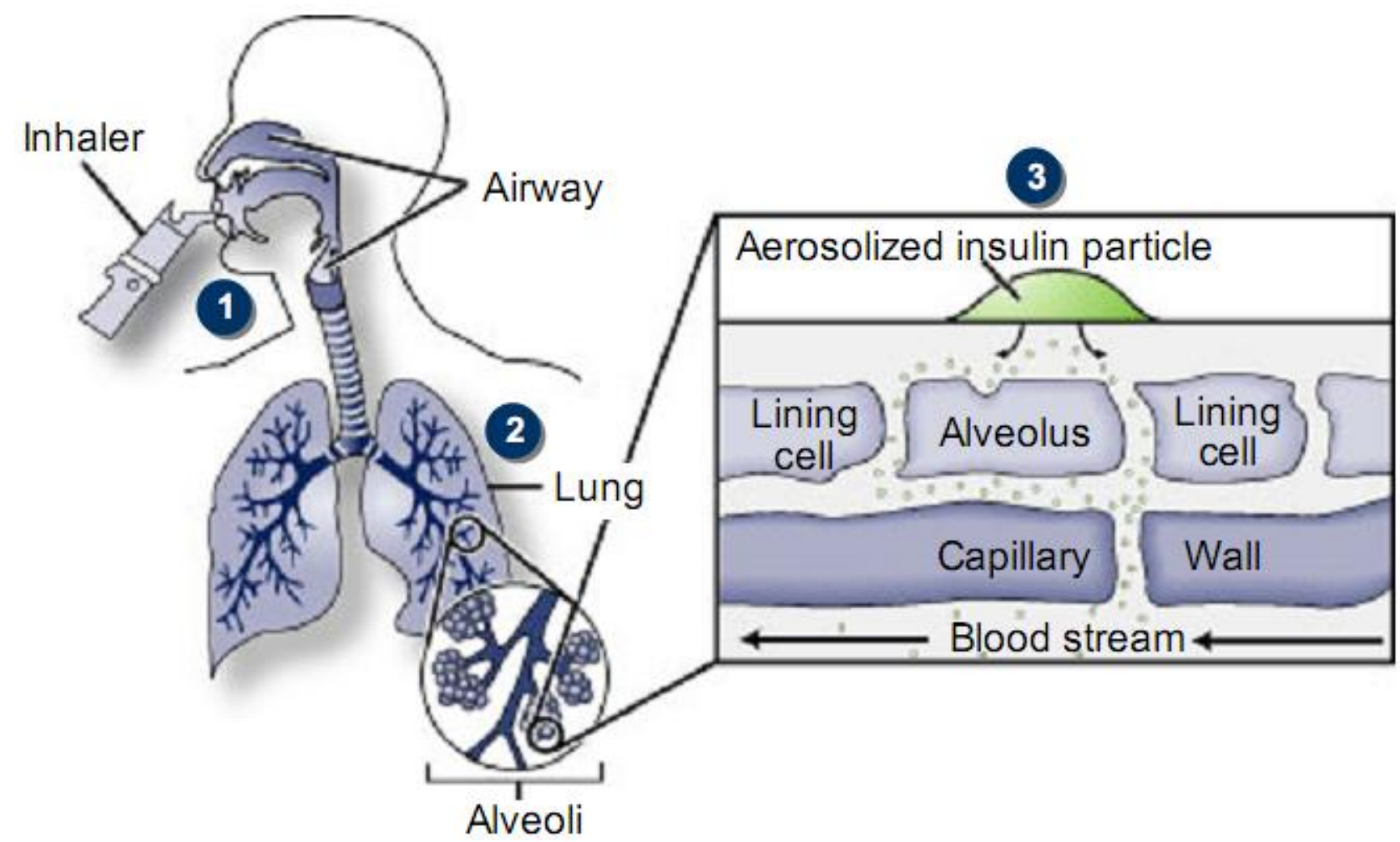

Figure 6: Inhalation of Insulin (Maheux).

fluorescein isothiocyanate dextran (FD-4) (Tozaki et al., 2001). In vitro drug-release experiments were carried out according to Japanese Pharmacopoeia XII (rotating basket method). The release of FD-4 from the pellets in phosphate buffered saline was very small. However, the release of FD-4 was markedly increased in the presence of rat ceacal contents. The pharmacodynamic studies of the azopolymer-coated pellets containing these peptides with camostat mesilate (protease inhibitor) were carried out by measuring the hypoglycemic effects. A slight decrease in plasma-glucose levels was observed following the oral administration of these pellets containing $12.5 \mathrm{IU}$ of insulin compared with the same dose of insulin solution. The authors concluded that azopolymer-coated pellets with protease inhibitor might be useful carriers for the colon-specific delivery of insulin.

Yakugaku Zasshi developed two types of microcapsular devices containing new acrylatebased nanogels with a specific solute-permeability for the delayed- or thermosensitive-release of peptide drugs (Ichikawa et al., 2007). A nanogelparticle of acrylic terpolymer, ethyl acrylate-methyl methacrylate-2-hydroxy-ethyl methacrylate, was newly synthesized by emulsion polymerization to construct delayed-release microcapsules. The insulin-loaded lactose particles were spray coated with the acrylic terpolymers. These microcapsules showed a pH-in-dependent delayed-release profile.

\section{Pulmonary approach}

Finally, insulin delivered through the oral cavity can also be considered to have its uptake in the pulmonary bed. However, the idea of pulmonary delivery of insulin is not a new idea, as the first report of inhaled insulin was noted in 1925 (Über et al., 1925) truly remarkable given that this was reported very shortly after the first clinical use of insulin. (Banting et al., 1922)The high permeability of the lung's large surface area makes it an ideal route for the administration of insulin. The lung has hundreds of millions of alveoli that are richly vascularised and where drug absorption takes place. In addition, the surface area is quite large, as the alveolar capillaries provide a total surface area of 50-140 $\mathrm{m}^{2}$ for absorption (Heinemann et al., 2002).

Insulin delivered in this way is believed to be transported across the alveolar cells by transcytosis, but this has yet to be conclusively proven. Once 


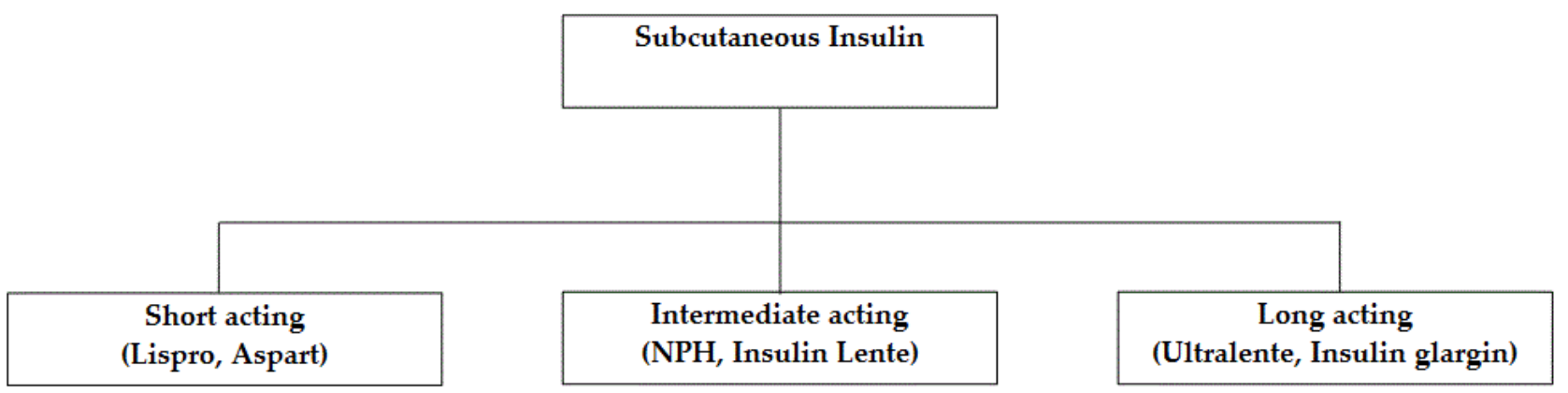

Figure 3: Classification of insulin according to their activity period (Galloway et al., 1993; Howey et al., 1994; Campbell et al., 1996; Home et al., 1998; Browne et al., 2000; Lopre et al., 2000; Lantus et al., 2001; White et al., 2003; Nielsen et al., 2005; Calara et al., 2005; DeFronzo et al., 2005; Sarabu et al., 2005).

deposited in the alveoli, the inhaled insulin molecules are taken up into vesicles, transported across the epithelial cells and then released into the interstitial fluid between the epithelium and the alveolar capillary endothelium. The insulin is once again taken up into vesicles, transported across the capillary endothelium and released into the bloodstream, where it exerts a rapid systemic effect (Wigley et al., 1971; Pilcher et al., 1987; Klonoff et al., 1999). This process is extremely rapid and pulmonary uptake results in a very rapid peak in insulin levels, that is, after 15-20 minutes (Enzmann et al., 1984; Adams et al., 1992). Therefore, the physiological and anatomic barriers that limit successful implementation of other routes of noninvasive insulin delivery do not appear to be a major concern when one considers the feasibility of pulmonary delivery of insulin, based in large part on the favorable anatomy of the lung.

Inhaled insulin claimed to have similar efficacy to injected insulin, both in terms of controlling glucose levels and blood half-life. Currently, inhaled insulin is short acting and is typically taken before meals; an injection of long-acting insulin at night is often still required (Nice et al., 2006). When patients were switched from injected to inhaled insulin, no significant difference was observed in $\mathrm{Hb}_{\mathrm{Alc}}$ levels over three months. Accurate dosing was a particular problem, although patients showed no significant weight gain or pulmonary function decline over the length of the trial, when compared to the baseline (Cefalu et al., 2001).

The Exubera ${ }^{\circledR}$ insulin formulation is a spray-dried, amorphous insulin powder containing $60 \%$ insulin in a buffered, sugar based matrix. In January 2006, Pfizer and its partner Nektar Therapeutics received marketing approval for Exubera ${ }^{\circledR}$, their insulin DPI. It was available from September 2006 to October 2007 in the United States. It is licensed for use by both type 1 and type 2 diabetes patients. As of October 18, 2007, Pfizer has announced that it will no longer manufacture or market Exubera ${ }^{\circledR}$, because it failed to gain acceptance of patients and physicians (Imam, 2011).

Table 2: Characteristics of modern insulin formulation (Illinois Extension, 2003; Cefalu et al., 2004; Modi et al., 2007).

\begin{tabular}{|c|c|c|c|c|}
\hline Insulin formulation & Mechanism of action & On set of action & $T_{\max }$ & Duration of action \\
\hline Lispro/Aspart ${ }^{\circledR}$ & $\begin{array}{l}\text { Dissociates into monomeric } \\
\text { formulation leading to rapid } \\
\text { absorption }\end{array}$ & $5-15 \mathrm{~min}$ & $1-2 \mathrm{hr}$ & $4-6 \mathrm{hr}$ \\
\hline Human regular ${ }^{\circledR}$ & Unknown & $30-60 \mathrm{~min}$ & $2-4 \mathrm{hr}$ & $6-10 \mathrm{hr}$ \\
\hline NPH/Lente® & $\begin{array}{l}\text { Produces insulin through } \\
\text { hormone conversion }\end{array}$ & $1-2 \mathrm{hr}$ & $4-8 \mathrm{hr}$ & $10-20 \mathrm{hr}$ \\
\hline Human ultralente ${ }^{\circledR}$ & Unknown & $2-4 \mathrm{hr}$ & Unpredictable & $16-20 \mathrm{hr}$ \\
\hline Glargine ${ }^{\circledR}$ & Unknown & $1-2 \mathrm{hr}$ & Flat & Up to $24 \mathrm{hr}$ \\
\hline
\end{tabular}


Table 3: Different approaches of oral insulin delivery.

\begin{tabular}{|c|c|c|}
\hline Characteristics & Approaches & Reference \\
\hline \multirow[t]{3}{*}{ Depending on $\mathrm{b}$} & Enzyme Inhibitors & $\begin{array}{l}\text { Fujji et al., 1985; Saffran et al., 1986; ziv et al., 1987; Yamamoto et al., } \\
\text { 1994; Patki et al., 1996; Chang et al., } 1999 \text { Agarwal et al., 2001; Shah et } \\
\text { al., 2002; Liu et al., } 2003 \text { Tuesca et al., } 2006\end{array}$ \\
\hline & Penetration Enhancers & $\begin{array}{l}\text { Koosapur et al., 1999; Schiling et al., 1999; Soltero et al., 2001, Thanou } \\
\text { et al., 2001; Eaimtarakam et al., 2002; Plate et al., 2002; } \\
\text { Gowthamarajan et al., 2003; Salamat-Miller et al., 2005; Toriska et al., } \\
\text { 2005; Rieux et al., 2006; Lin et al., } 2007\end{array}$ \\
\hline & Dosage form stability & Pearlman et al., 1991; Agarwal et al., 2001 \\
\hline \multirow{8}{*}{$\begin{array}{l}\text { Technology } \\
\text { dependent }\end{array}$} & Liposomes & Choudhari et al., 1994 \\
\hline & Coated liposomes & $\begin{array}{l}\text { Cantenys et al., 1983; Ramadas et al., 2000; Ye et al., 2000; Wu et al., } \\
\text { 2004; Zhang et al., 2005 }\end{array}$ \\
\hline & Hydrogel & $\begin{array}{l}\text { Yupeng et al., 2001; Dorkoosh et al., 2002; Nakamura et al., 2004; } \\
\text { Kavimandan et al., } 2006\end{array}$ \\
\hline & Nanoparticle & $\begin{array}{l}\text { Damage et al., 1997; Attivi et al., 2005; Sarmento et al., 2006; } \\
\text { Tiyaboonchai et al., 2006; Damage et al., 2007; Chalasani et al., 2007; } \\
\text { Lin et al., 2007; Cui et al., 2007; Simon et al., 2007 }\end{array}$ \\
\hline & Erythrocytes & Al-Achi et al ., 1998 \\
\hline & Nanocubicles & Chung et al., 2004 \\
\hline & Microparticles & $\begin{array}{l}\text { Lowman et al., 1999; Tozaki et al., 2001; Peppas et al., 2004; Qi et al., } \\
\text { 2004; Senthil et al., 2004; kim et al., 2005; Reis et al., 2007; Ubaidulla et } \\
\text { al., } 2007\end{array}$ \\
\hline & Mucoadhesive system & Whitehead et al., 2004 \\
\hline \multirow{4}{*}{$\begin{array}{l}\text { Formulation } \\
\text { dependent }\end{array}$} & Tablet & Krauland et al., 2004 \\
\hline & Microemulsions & Cho et al., 1989; Ritschel et al., 1992; Torisaka et al., 2005 \\
\hline & Oral insulin pills & Kinesh et al., 2010 \\
\hline & Oral spray & Kinesh et al., 2010 \\
\hline
\end{tabular}

\section{ORAL DELIVERY: THE CHALLENGE}

\section{Obstacles of Oral insulin Delivery}

Generally, peptides and proteins such as insulin cannot be administered via the oral route due to rapid enzymatic degradation in the stomach, inactivation and digestion by proteolytic enzymes in the intestinal lumen, and poor permeability across intestinal epithelium because of its high molecular weight and lack of lipophilicity (Nakamura et al., 2004; Jain et al., 2005; Sajeesh et al., 2006).The oral bioavailability of most peptides and proteins therefore is less than $1 \%$. The challenge here is to improve the bioavailability to anywhere between 30-50\% (Lee et al., 1991).

\section{Enzymatic Barrier}

The harsh environment of the gastrointestinal tract (GIT) causes insulin to undergo degradation. This is because digestive processes are designed to breakdown proteins and peptides without any discrimination (Tuesca et al., 2006). Insulin therefore undergoes enzymatic degradation by pepsin and pancreatic proteolytic enzymes such as trypsin and $\alpha$-chymotrypsin (Patki et al., 1996; Agarwal et al., 2001). Overall, insulin is subjected to acid catalyzed degradation in the stomach, luminal degradation in the intestine and intracellular degradation. The cytosolic enzyme that degrades insulin is insulindegrading enzyme (IDE) (Chang et al., 1999). Insulin is however not subject to proteolytic breakdown by brush border enzymes (Agarwal et al., 2001). Insulin can be presented for absorption only if the enzyme attack is either reduced or defeated.

\section{Intestinal Transport of Insulin}

Another major barrier to the absorption of hydrophilic macromolecules like insulin is that they cannot diffuse across epithelial cells through lipid bilayer cell membranes to the blood stream (Lin et al., 2007). In other words, insulin has low permeability through the intestinal mucosa (Torisaka et al., 2005). There is no evidence of active 
Table 4: Market status of non-invasive products.

\begin{tabular}{llll}
\hline Brand Name & Dosage form & Company name & Launching year / Status \\
\hline Exubera ${ }^{\circledR}$ & Powder Inhaler & Pfizer & 2006 \\
Oral-lyn ${ }^{\circledR}$ & Oral spray & Generex Biotechnology & 2007 \\
Nasulin ${ }^{\circledR}$ & Nasal spray & CPEX Pharmaceuticals & 2010 \\
Transgene ${ }^{\circledR}$ & Nanoparticles & Biotek & Human trial ongoing \\
In-105® & Tablet & Biocon & Phase-II trial ongoing \\
ORMD- $0801 \circledR$ & Capsule & Oramed Pharmaceuticals & Phase II b complete \\
\hline
\end{tabular}

transport for insulin (Schilling et al., 1999). It has been found however that insulin delivery to the midjejunum protects insulin from gastric and pancreatic enzymes and release from the dosage form is enhanced by intestinal microflora (Koosapur et al., 1999; Schilling et al., 1999). Various strategies have been tried out to enhance the absorption of insulin in the intestinal mucosa and in some cases; they have proven successful in overcoming this barrier.

\section{Dosage form Stability}

The activity of proteins depends on the three dimensional molecular structure. During dosage form development, proteins might be subject to physical and chemical degradation. Physical degradation involves modification of the native structure to a higher order structure while chemical degradation involving bond cleavage results in the formation of a new product (Agarwal et al., 2001). Proteins must be characterized for change in conformation, size, shape, surface properties, and bioactivity upon formulation processing. Changes in conformation, size, and shape can be observed by spectrophotometric techniques, X-ray diffraction, differential scanning calorimetery, light scattering, electrophoresis, and gel filtration (Pearlman et al., 1991).

\section{Approaches for oral insulin delivery}

Most peptides are not bioavailable from the GIT after oral administration (Kinesh et al., 2010, Cho et al., 1989). Therefore, successful oral insulin delivery involves overcoming the enzymatic and physical barriers (Tuesca et al., 2006) and taking steps to conserve bioactivity during formulation processing (Agarwal et al., 2001). In developing oral protein delivery systems with high bioavailability, three practical approaches might be most helpful (Morishita et al., 2006):
1. Modification of physicochemical properties such as lipophilicity and enzyme susceptibility.

2. Addition of novel function to macromolecules.

3. Use of improved carrier systems.

\section{CONCLUSION}

Insulin is the only treatment for type-2 diabetes patient. From 1922 to till date various attempt have been made to achieve different route of administration of insulin. After subcutaneous route, inhalation route has comparable bioavailability but inhaler insulin is rejected by patient and physician. Now-a-days a lot of research subjected for oral delivery of insulin. Liposome, microemulsion, hydrogels, nanoparticles etc. have been investigated and prepared for the oral delivery of insulin.

\section{REFERENCES}

Agarwal, V., Khan, M.A. (2001). Current status of the oral delivery of insulin. Pharm. Tech. 25(10): 76-90.

Agarwal, V., Reddy, I.K., Khan, M.A. (2001).

Polyethylacrylate based microparticulate of insulin for oral delivery: preparation and in vitro dissolution stability in the presence of enzyme inhibitors. Int. J Pharm.; 225 (1-2), 31-39. http://dx.doi.org/10.1016/S0378-5173(01)00740-2

Ahmed, I., Goldstein, B. (2006) Diabetes Mellitus, Clin. Dermatol. 24 (4): 237-246. [DOI]

Al-Achi, A., Greenwood, R. (1998). "Erythrocytes as Oral Delivery Systems for Human Insulin," Drug Dev Ind Pharm 24 (1): 67-72.

http://dx.doi.org/10.3109/03639049809082354 PMid:15605599

American Diabetes Association, Implications of the United Kingdom Prospective Diabetes Study. Diabetes Care 26 (suppl 1), S28 -S32, (2003).

http://dx.doi.org/10.2337/diacare.26.2007.S28

Arbit, E., and Miriam K. (2009). Oral Insulin: The Rationale for This Approach and Current Developments. Journal of Diabetes Science and Technology 3: 562-567. 
Arora, A, Hakim, I., Baxter, J. (2007). Needle-free delivery of macromolecules across the skin by nanoliter-volume pulsed microjets. Proc. Natl. Acad. Sci. U.S.A. 104 (11): 4255-4260. http://dx.doi.org/10.1073/pnas.0700182104 PMid:17360511 PMCid:1838589

Attivi, D. (2005). "Formulation of Insulin-Loaded Polymeric Nanoparticles using Response Surface Methodology," Drug Dev. Ind. Pharm. 31 (2), 179-189. http://dx.doi.org/10.1081/DDC-200047802 PMid:15773285

Balsells, M., Corcoy, R., Mauricio, D., Morales, J., GarciaPatterson, A., Carreras, G., Puig-Domingo, M., de Leiva, A. (1997). Insulin antibody response to a short course of human insulin therapy in women with gestational diabetes. Diabetes Care; 20:1, 1172-1175. http://dx.doi.org/10.2337/diacare.20.7.1172 PMid:9203458

Banting, F.G. (1922). "Pancreatic Extracts," J. Lab. Clin. Med. $7,464-472$

Banting, F.G., Best, C.H. (1922). The internal secretion of the pancreas. J Lab Clin Med; 7: 465-480.

Bliss, M. (1982). The Discovery of Insulin. Chicago, University of Chicago Press, p 155.

Bohannon, N.J.V. (1999). Insulin delivery using pen devices: simple-to-use tools may help young and old alike.

Postgrad Med 106: 57-68.

http://dx.doi.org/10.3810/pgm.1999.10.15.751

Browne, D.L., Avery, L., Turner, B.C. (2000). What do patients with diabetes know about their tablets? Diabet.Med. 17, 528-531. http://dx.doi.org/10.1046/j.1464-5491.2000.00327.x PMid:10972583

Calara, F., Taylor, K., Han, J., Zabala, E., Carr, E.M., Wintle, M., Fineman, M. (2005). A randomized, openlabel,crossover study examining the effect of injection site on bioavailability of exenatide (synthetic exendin-4). Clin. Ther. 27(2), 210-215. http://dx.doi.org/10.1016/j.clinthera.2005.02.008 PMid:15811484

Campbell, R.K., Campbell, L.K., White, J.R. (1996). Insulin lispro: its role in the treatment of diabetes mellitus.Ann. Pharmacother. 30, 1263-71. PMid:8913409

Cefalu, W., Skyler, J., Kourides, I., Landschulz, W., Balagtas, C., Cheng, S., Gelfand, R. (2001). "Inhaled human insulin treatment in patients with type 2 diabetes mellitus". Ann Intern Med 134 (3): 203-7. PMid:11177333

Cefalu, W.T. (2004). Evolving Straegies for insulin delivery and theapy, drugs 64 (11), 1149-1161.

Chalasani, K.B. (2007). A Novel Vitamin B12-Nanosphere Conjugate Carrier System for Peroral Delivery of Insulin, J Control Release 117 (3), 421-429 Epub 2006.

Cho, Y.W., Flynn, M. (1989). Oral delivery of insulin. Lancet; 1518-1519. http://dx.doi.org/10.1016/S0140-6736(89)92954-1
Chung, H. (2004)."Self-Assembled 'Nanocubicle' as a Carrier for Peroral Insulin Delivery," Diabetologia 45 (3), 448-451. http://dx.doi.org/10.1007/s00125-001-0751-z PMid:11914752

Coates, P.A., Ismail, I.S., Luzio, S.D. (1995). Intranasal insulin: the effects of three dose regimens on postprandial glycaemic profiles in type II diabetic subjects. Diabet Med; 12: 235-239. PMid:7758260 [DOI]

Cui, F.D. (2007). Preparation of Insulin-Loaded PLGA-Hp55 Nanoparticles for Oral Delivery, J. Pharm Sci. 96 (2), 421427. http://dx.doi.org/10.1002/jps.20750 PMid:17051590

Damge, C. (1997). Poly (alkyl cyanoacrylate) Nanospheres for Oral Adminiatration of Insulin, J Pharm Sci. 86 1403-1409. http://dx.doi.org/10.1021/js970124i PMid:9423155

Damge, C., Maincent, P., Ubrich, N. (2007). Oral Delivery of Insulin Associated to Polymeric Nanoparticles in Diabetic Rats, J Control Release 117 (2), 163-170, Epub 2006. http://dx.doi.org/10.1016/j.jconrel.2006.10.023 PMid:17141909

DeFronzo, R.A., Bergenstal, R.M., Cefalu, W.T. (2005). Efficacy of inhaled insulin in patients with type 2 diabetes not controlled with diet and exercise. Diabetes Care 28, 1922-1928. http://dx.doi.org/10.2337/diacare.28.8.1922 PMid:16043733

Defronzo, R.A., Ratner, R.E., Han, J., Kim, D.D., Fineman, M.S., Baron, A.D. (2005). Effects of exenatide(exendin-4) on glycemic control and weight over 30 weeks in metformintreated patients with type 2 diabetes. Diabetes Care 28(5), 1092-1100. http://dx.doi.org/10.2337/diacare.28.5.1092 PMid:15855572

Dhawan, S., Chopra, S. (2009). Novel approaches for oral delivery. Pharmaceutical Technology 33(7).

Dixit, N., Bali, V., Baboota, S., Ahuja, A., Ali, J. (2007). Iontophoresis - an approach for controlled drug delivery: a review. Current drug delivery 4 (1): 1-10. http://dx.doi.org/10.2174/156720107779314802 PMid:17269912

Dorkoosh, F.A. (2002). Peroral Delivery Systems based on Superporous Hydrogel Polymers: Release Characteristics for the Peptide Drugs Buserelin, Octreotide and Insulin, Eur J Pharm Sci 15 (5), 433-439. http://dx.doi.org/10.1016/S0928-0987(02)00028-3

Eaimtrakarn, S., Ramaprasad, Y.V., Ohno, T., Konishi, T., Yoshikawa, Y., Shibata, N. (2002). Absorption-enhancing effect of labrasol on the intestinal absorption of insulin in rats. J. Drug Target. 10 (3), 255-260. http://dx.doi.org/10.1080/10611860290022688 PMid:12075827

Elliott, R.B., Edgar, B.W., Pilcher, C.C. (1987). Parenteral absorption of insulin from the lung in diabetic children. Aust Paediatr J 23: 293-297. PMid:3326575

Fujii, S., Yokoyama, T., Ikegaya, K., Sato, F., Yokoo, N. (1985). Promoting effect of the new chymotrypsin inhibitor fk-448 on the intestinal absorption of insulin in rats and dogs. J. 
Pharm. Pharmacol. 37 (8), 545-549.

http://dx.doi.org/10.1111/j.2042-7158.1985.tb03064.x PMid:2864414

Galloway, J.A. (1993). New directions in drug development: mixtures, analogues, and modeling. Diabetes Care16(3), S16-S23.

Gänsslen, M., Über (1925) Inhalation von Insulin [abstract]. Klin Wochenschr 4: 71. http://dx.doi.org/10.1007/BF01748135

Gedulin, B.R., Nikoulina, S.E., Smith, P.A., Gedulin, G., Nielsen, L.L., Baron, A.D., Parkes, D.G., Young, A.A. (2005). Exenatide (exendin-4) improves insulin sensitivity and \{beta\}-cell mass in insulin-resistant obesefa/fa Zucker rats independent of glycemia and body weight.

Endocrinology 146(4), 2069-76.

http://dx.doi.org/10.1210/en.2004-1349 PMid:15618356

Giriraj K.G., Giriraj K.T. (2003). Oral Insulin-Fact or Fiction. Resonance 38-43.

Gizurarson, S., Bechgaard, E. (1991). Intranasal administration of insulin to humans. Diabetes Res Clin Pract 12: 71-84. [DOI]

Golden, M.P., Haymond, M., Hinnen, D.A. (1988). Position statement on jet injectors. Diabetes Care 11: 600-1. PMid:3060330

Gowthamarajan, K., Kulkarni, G.T. (2003). Oral Insulin - Fact or Fiction? Possibilities of achieving oral delivery for insulin. Resonance, 38-46.

Graff, M.R., McClanahan, M.A. (1998). Assessment by patients with diabetes mellitus of two insulin pen delivery systems versus a vial and syringe. Clin Ther 20: 486-96. http://dx.doi.org/10.1016/S0149-2918(98)80058-1

Heinemann, L. (2002). Alternative delivery routes: inhaled insulin. Diabetes Nutr Metab Dec; 15 (6): 417-22.

Heinemann, L., Heise, T., Wahl, L.C. (1996). Prandial glycaemia after a carbohydrate-rich meal in type I diabetic patients: using the rapid acting insulin analogue [Lys(B28), Pro(B29)] human insulin. Diabet Med; 13: 625-9.

Heinemann, L., Pfutzner, A., Heise, T. (2001). Alternative routes of administration as an approach to improve insulin therapy: update on dermal, oral, nasal and pulmonary insulin delivery. Curr Pharm Des Sep; 7 (14): 1327-51.

Hilsted J., Madsbad S., Hvidberg A. (1995). Intranasal insulin therapy: the clinical realities. Diabetologia; 38: 680-4. http://dx.doi.org/10.1007/BF00401839 PMid:7672489

Ho, L.T., Lam, H.C., Wu, M.S., Kwok, C.F., Jap, T.S., Tang, K.T., Wang, L.M., Liu, Y.F. (1991). A twelve month doubleblind randomized study of the efficacy and immunogenicity of human and porcine insulins in noninsulin-dependent diabetics. Zhonghua Yi Xue Za Zhi (Taipei); 47:313-319.

Home, P.D., Lindholm, A., Hylleberg, B. (1998). The UK Insulin Aspart Study Group. Improved glycemic control with insulin aspart. Diabetes Care; 21: 1904-9. http://dx.doi.org/10.2337/diacare.21.11.1904 PMid:9802741

Howey, D.C., Bowsher, R.R., Brunelle, R.L., Woodworth, J.R. (1994). [Lys(B28), Pro(B29)]-human insulin, Arapidly absorbed analogue of human insulin. Diabetes 43, 396-402. http://dx.doi.org/10.2337/diabetes.43.3.396 PMid:8314011

Hunt, L.M., Valenzuela, M.A., Pugh, J.A. (1997). NIDDM patients' fears and hopes about insulin therapy. Diabetes Care; 20: 292-8. http://dx.doi.org/10.2337/diacare.20.3.292 PMid:9051375

I.L., Sytov, G.A. (2002). Mucoadhesive polymers with immobilized proteinase inhibitors for oral administration of protein drugs. Biomaterials; 23 (7), 1673-1677.

Ichikawa, H., Fukumori, Y. (2007). "Design of NanohydrogelIncorporated Microcapsules for Appropriate ControlledRelease of Peptide Drugs," Yakugaku Zasshi 127 (5), 813823. http://dx.doi.org/10.1248/yakushi.127.813 PMid:17473523

Imam, M.Z. (2011). Pharmaceutical Dosage Forms, publisher Altaf Medical Book Center, Dhaka, Bangladesh pp393.

Jacobs, M., Schreuder, R.H., Jap-A-Joe, K. (1993). The pharmacodynamics and activity of intranasally administered insulin in healthy male volunteers. Diabetes; 42: 1649-55. http://dx.doi.org/10.2337/diabetes.42.11.1649 PMid:8405708

Jain, D., Panda, A.K., Majumdar, D.K. (2005). Eudragit S100 entrapped insulin microspheres for oral delivery. AAPS PharmSciTech,6 (1): 1-27. http://dx.doi.org/10.1208/pt060116 PMid:16353953 PMCid:2750417

Jersild, M. (1956). Insulin zinc suspension; four years experience. Lancet; 271:1009-1013. http://dx.doi.org/10.1016/S0140-6736(56)90266-5

Kanikkannan, N., Singh, J., Ramarao, P. (1999). Transdermal iontophoretic delivery of bovine insulin and monomeric human insulin analogue. J Control Release; 59: 99-105. http://dx.doi.org/10.1016/S0168-3659(98)00184-9

Katsoyannis, P.G., Tometsko, A., Zalut, C. (1966). Insulin peptides XII. Human insulin generation by combination of synthetic A and B chains. J Am Chem Soc 88:186. http://dx.doi.org/10.1021/ja00953a048

Kavimandan, N.J. (2006). Synthesis and Characterization of Insulin-Transferrin Conjugates, Bioconjug Chem. 17 (6), 1376-1384. http://dx.doi.org/10.1021/bc050344k PMid:17105214 PMCid:2547411

Keen, H., Glynne, A., Pickup, J.C. (1980). Human insulin produced by recombinant DNA technology: safety and hypoglycaemic potency in healthy men. Lancet; ii: 398-401. http://dx.doi.org/10.1016/S0140-6736(80)90443-2

Kinesh, V.P., Neelam, D.P. (2010). Novel approaches for oral delivery of Inslin and current status of oral insulin 
products. International Journal of pharmaceutical Sciences and Nanotechnology; 3(3):1057-1064.

Klonoff, D.C. (1999). Inhaled insulin. Diabetes Technol Ther 1: 307-13. http://dx.doi.org/10.1089/152091599317224

Kooshapur, H., Chaideh, M. (1999). Intestinal transport of human insulin in rat. Med. J. Islamic Academy of Sciences; $12: 1,5-11$.

Kraeling, M.E., Ritschel, W.A. (1992). Development of a Colonic Release Capsule Dosage Form and the Absorption of Insulin, Methods Find Exp Clin Pharmacol 14 (3), 199 209. PMid:1378164

Krauland, A.H., Guggi D., and Bernkop-Schnurch A., (2004). Oral Insulin Delivery: The Potential of Thiolated ChitosanInsulin Tablets on Nondiabetic Rats, J Control Release 95 (3): 547-55. http://dx.doi.org/10.1016/j.jconrel.2003.12.017 PMid:15023465

Kung, Y.T., Da, Y.C., Huang, W.T. (1966). Total synthesis of crystalline insulin. Sci Sin; 15:544. PMid:5960685

Lantus [package insert]. Kansas City (MO): Aventis Pharmaceuticals, 2001.

Laube, B.L., Georgopoulos, A., and Adams, III, G.K. (1992). Proving the efficacy of insulin delivered through the lungs as an aerosol. J. Biopharm. Sci. 3:163-169.

Lee, V.H. (1991). Oral route of peptide and protein drug delivery In Peptide and Protein Drug Delivery, Chapter 16, Marcel Dekker Inc.,New York, 691-738.

Lepore, M., Pampanelli, S., Fanelli, C. (2000). Pharmacokinetics and pharmacodynamics of subcutaneous injection of long-acting human insulin analog glargine, NPH insulin, and ultralente human insulin and continuous subcutaneous infusion of insulin lispro. Diabetes; 49 (12): 2142-8. http://dx.doi.org/10.2337/diabetes.49.12.2142 PMid:11118018

Li, C.L., Deng, Y.J. (2004). Oil-based formulations for oral delivery of insulin. J. Pharm. Pharmacol. 56 (9): 1101-1107. http://dx.doi.org/10.1211/0022357044175 PMid:15324478

Lin, Y.H (2007). Preparation and Characterization of Nanoparticles Shelled with Chitosan for Oral Insulin Delivery, Biomacromolecules 8 (1): 146-152. http://dx.doi.org/10.1021/bm0607776 PMid:17206800

Maheux, P., The evolving story of insulin delivery, Inhaled insulin [Presentation given at Pfizer Ltd].

Major, R.H. (1935). The intranasal application of insulin. J Lab Clin Med; 21: 278-80.

Meienhofer, J., Schnabel, E., Bremer, H. (1963). Synthese der Insulinketten und ihre Kombination zu insulactiven Präparaten. Z Naturforsch; 18:1120. PMid:14117584

Mitragotri, S., Blankschtein, D., Langer, R. (1995). Ultrasoundmediated transdermal protein delivery. Science; 269: 850-3. http://dx.doi.org/10.1126/science.7638603 PMid:7638603
Morishita, M, Peppas, NA. (2006). Is the oral route possible for peptide and protein drug delivery? Drug Discovery Today. 11: 19-20.

http://dx.doi.org/10.1016/j.drudis.2006.08.005

PMid:16997140

Nakamura, K., Murray, R.J., Joseph J.I., Peppas N.A., Morishita M., Lowman A.M. (2004). Oral insulin delivery using P(MAA-g-EG) hydrogels: Effects of network morphology on insulin delivery characteristics. J. Cont. Release, 95:589-599.

http://dx.doi.org/10.1016/j.jconrel.2003.12.022 PMid:15023469

Nauck, M.A., Meier, J.J. (2005). Glucagon-like peptide 1 and its derivatives in the treatment of diabetes. Regul. Pept. 128(2), 135-48.

http://dx.doi.org/10.1016/j.regpep.2004.07.014

PMid:15780433

NICE (2006). Diabetes (type 1 and 2), Inhaled Insulin Appraisal Consultation Document (second). Retrieved 2006-07-26.

Nielsen, L.L. (2005). Incretin mimetics and DPP-IV inhibitors for the treatment of type 2 diabetes. D.D.T, 10,703-710.

Pamnani, D. (2008). Reality Check on Oral Insulin, Pharma Express, 16-31.

Patki, V.P., Jagasia, S.H. (1996). Progress made in noninvasive insulin delivery. Ind. J. Pharmacol. 28: 143-151.

Pearlman, R., Nguyen, T.H. (1991). Analysis of Protein Drugs, in Peptide and Protein Drug Delivery, V.H.L. Lee, Marcel Dekker, NewYork, Plate, N.A., Valuev.

Rieux, A., Fievez, V., Garinot, M., Schneider, Y.J., Preat, V. (2006). Nanoparticles as potential oral delivery systems of proteins and vaccines: A mechanistic approach. J. Cont. Release; 116: 1-27. http://dx.doi.org/10.1016/j.jconrel.2006.08.013 PMid:17050027

Rosenstock, J. (2001). Insulin therapy: optimizing control in type 1 and type 2 diabetes. Clin Cornerstone; 4 (2): 50-64. http://dx.doi.org/10.1016/S1098-3597(01)90029-8

Saffran, M., Kumar, G.S., Savariar, C., Burnham, J.C., Williams, F., Neckers, D.C. (1986). A new approach to the oral administration of insulin and other peptide drugs. Science; 233(4768):1081-1084. http://dx.doi.org/10.1126/science.3526553 PMid:3526553

Sajeesh, S., Sharma, C.P. (2006). Cyclodextrin-insulin complex encapsulated polymethacrylic acid based nanoparticles for oral insulin delivery. Int. J. Pharm. 325(1- 2):147-154.

Salamat-Miller, N, Johnston, TP. (2005). Current strategies used to enhance the paracellular transport of therapeutic polypeptides across the intestinal epithelium. Int. J. Pharm. 294: 201-216 http://dx.doi.org/10.1016/j.ijpharm.2005.01.022 PMid:15814245 
Sarabu, R., Grimsby, J. (2005). Targeting glucokinase activation for the treatment of type 2 diabetes - a status review. Curr. Opin. Drug. Discov. Devel. 8, 631-637 PMid:16159025

Sarmento, B. (2006). Development and Characterization of New Insulin Containing Polysaccharide Nanoparticles, Colloids Surf B. Biointerfaces 53 (2), 193-202. http://dx.doi.org/10.1016/j.colsurfb.2006.09.012 PMid:17049214

Saudek, C.D. (1997). Novel forms of insulin delivery. Endocrinol Metab Clin North Am; 26: 599-610 http://dx.doi.org/10.1016/S0889-8529(05)70269-3

Sayani, A.P., Chien, Y.W. (1996). Systemic delivery of peptides and proteins across absorptive mucosae. Crit Rev Ther Drug Carrier Syst; 13: 85-184. PMid:8853960

Schilling, R.J., Mitra, A.K. (1999). Intestinal mucosal transport of insulin. Int. J. Pharm. 62: 53-64. http://dx.doi.org/10.1016/0378-5173(90)90030-8

Schlüter, K.J., Köhler, D., Enzmann, F. (1984) Pulmonary administration of human insulin in volunteers and type 1 diabetics [abstract]. Diabetes; 75A: 298.

Shah, R.B., Ahsan, F., Khan, M.A. (2002). Oral delivery of proteins: Progress and prognostication. Crit. Rev. Ther. Drug Carrier Syst. 19(2): 135-169. http://dx.doi.org/10.1615/CritRevTherDrugCarrierSyst.v19. i2.20 PMid:12197608

Simon, M. (2007). Nanosized Insulin-Complexes based on BioDegradable Amine-Modified Graft Polyesters Poly(vinyl-3-(diethylamino)-propylcarbamate-co-(vinyl acetate)-co-(vinyl alcohol)]-graft-poly(l-lactic acid): Protection Against Enzymatic Degradation, Interaction with Caco-2 Cell Monolayers, Peptide Transport and Cytotoxicity, Eur. J. Pharm. Biopharm. 66 (2), 165-172. http://dx.doi.org/10.1016/j.ejpb.2006.10.009 PMid:17150341

Soltero, R., Ekwuribe, N. (2001). The oral delivery of protein and peptide drugs- A report. Innovat. Pharmaceut. Technol. 1:106-110.

Spencer, A.G., Morgans M.E. (1956). Lente insulin; four years' experience. Lancet; 271: 1013-1017. http://dx.doi.org/10.1016/S0140-6736(56)90267-7

Teuscher, A. (1974). Treatment of insulin lipoatrophy with monocomponent insulin. Diabetologia; 10: 211-214. http://dx.doi.org/10.1007/BF00423037 PMid:4845721

Teuscher, A. (1979). The biological effect of purely synthetic human insulin in patients with diabetes mellitus. Schweiz Med Wochenschr; 109: 743-747. PMid:451498

Thanou, M., Verhoef, J.C., Junginger H.E. (2001). Chitosan and its derivatives as intestinal absorption enhancers. Adv. Drug. Delivery. 50: S91-S101. http://dx.doi.org/10.1016/S0169-409X(01)00180-6
Tiyaboonchai, W. (2003). Insulin Containing Polyethylenimine-Dextran Sulfate Nanoparticles," Int. J. Pharm. 255 (12): 139-151. http://dx.doi.org/10.1016/S0378-5173(03)00055-3

Toorisaka, E, Hashida M, Kamiya N, Ono H, Kokazu Y, Goto M. (2005). An enteric-coated dry emulsion formulation for oral insulin delivery. J. Cont. Release; 107: 91-96. http://dx.doi.org/10.1016/j.jconrel.2005.05.022 PMid:16039746

Tozaki, H. (2001) Enhanced Absorption of Insulin and (Asu $(1,7)$ )eel-calcitonin Using Novel Azopolymer-Coated Pellets for Colon-Specific Drug Delivery," J. Pharm. Sci. 90 (1), 89-97. [DOI]

Troels Keldmann Nasal Delivery outlook Direct-haler A/S available at:

http://www.directhaler.com/search/directhaler-h118.htm [Accessed on 26 December 2011].

Tuesca, A., Lowman, A. (2006). The oral delivery of insulin using protein conjugates in complexation hydrogels. Poster presentation, Biomaterials and Drug Delivery Laboratory, Drexel University.

White, Jr J.R., Campbell, R.K., Hirsch, I.B. (2003) Novel insulins and strict glycemic control: analogues approximate normal insulin secretory response. Postgrad Med; 113 (6): 30-36. http://dx.doi.org/10.3810/pgm.2003.06.1426 PMid:12838802

Whitehead, K., Shen, Z., Mitragotri, S. (2004). Oral Delivery of Macromolecules Using Intestinal Patches: Applications for Insulin Delivery, J. Control. Release 98 (1), 37-45. http://dx.doi.org/10.1016/j.jconrel.2004.04.013 PMid:15245887

Wigley, F.W., Londono, J.H., Wood, S.H. (1971). Insulin across respiratory mucosa by aerosol delivery. Diabetes; 20: 552-556. PMid:5565002

Yamamoto, A., Taniguchi, T., Rikyuu, K., Tsuji, T., Fujita, T., Murakami, M., Mranishi, S. (1994). Effects of various protease inhibitors on the intestinal absorption and degradation of insulin in rats. Pharm. Res. 11 (10): 14961500. http://dx.doi.org/10.1023/A:1018968611962 PMid:7855059

Zambanini, A., Newson, R.B., Maisey, M. (1999). Injection related anxiety in insulin-treated diabetes. Diabetes Res Clin Pract; 46: 239-246. [DOI]

Ziv, E., Lior, O., Kidron, M. (1987). Absorption of protein via the intestinal walls: A quantitative model. Biochem. Pharmacol. 39(7):1035-1039. [DOI] 